\title{
Asymmetry of muscle strength in elite athletes
}

\author{
Patrik Drid ${ }^{1}$, Miodrag Drapsin², Tatjana Trivic ${ }^{1}$, Damir Lukač $^{2}$, Slavko Obadov ${ }^{1}$ Zoran Milosevic ${ }^{1}$ \\ 1Faculty of Sport and Physical Education Novi Sad, University of Novi Sad; 2 Medical Faculty, University of \\ Novi Sad, Serbia
}

\begin{abstract}
Summary
Study aim: To determine muscle strength variables in elite judoists and wrestlers since thigh muscle strength and bilaterally balanced flexor-to-extensor ratio minimise injury risk and are desirable for achieving sport successes.

Material and methods: Judoists, wrestlers and untrained subjects, 10 each, were subjected to isokinetic strength measurements of relative peak torques of knee flexor and extensor muscles on "Easy-Tech" dynamometer in concentric-concentric mode.

Results: Mean relative peak muscle torques for knee flexors ranged from $1.14 \pm 0.27$ (untrained) to $1.57 \pm 0.40$ (judoists) $\mathrm{N} \cdot \mathrm{m} / \mathrm{kg}$ and for knee extensors from $2.77 \pm 0.34$ (untrained) to $3.60 \pm 0.64$ (wrestlers) $\mathrm{N} \cdot \mathrm{m} / \mathrm{kg}$. The flexorto-extensor ratios ranged from $39.3 \pm 6.0$ to $47.8 \pm 10.8 \%$ and did not differ significantly between groups. Absolute right/left asymmetry for knee flexors ranged from $14.6 \pm 10.4$ to $17.4 \pm 11.8 \%$ and was significantly $(\mathrm{p}<0.01)$ higher than for knee extensors $(7.2 \pm 6.8$ to $8.6 \pm 7.7 \%)$. All asymmetry indices were significant $(\mathrm{p}<0.01)$, no significant between group differences being detected.

Conclusions: Implementing new training elements and modalities may improve the performance and prevent lateral asymmetry thus decreasing the risk of injuries.
\end{abstract}

Key words: Functional asymmetry - Muscle strength - Peak torque - Judo - Wrestling

\section{Introduction}

The contemporary competitive combat sports are highly demanding with respect to physical fitness not only for achieving sport successes but for minimising the risk of injuries as well. During a high-intensity action in judo, the contestants are trying to throw each other on the back or to control the opponent in the ground phase $[7,12]$. Similarly, wrestling (Greco-Roman style) is one of the most demanding sports from a metabolic perspective, in which supreme strength and power are critical $[4,9]$. In both sports the strength of lower extremities is the most important one [5], therefore, maximal muscle strength and endurance are subjects of continuous monitoring, isokinetic measurements being amongst the most widely used in that respect. The aim of the study was thus to determine muscle strength variables in elite judoists and wrestlers in order to detect possible differences and similarities.

\section{Material and Methods}

Three groups of subjects volunteered to participate in the study: 10 elite judoists, 10 elite wrestlers (Greco-
Roman style) and 10 untrained individuals. Their physical characteristics are presented in Table 1.

Table 1. Physical characteristics of subjects studied

\begin{tabular}{lccc}
\hline & $\begin{array}{c}\text { Judoists } \\
(\mathrm{n}=10)\end{array}$ & $\begin{array}{c}\text { Wrestlers } \\
(\mathrm{n}=10)\end{array}$ & $\begin{array}{c}\text { Untrained } \\
(\mathrm{n}=10)\end{array}$ \\
\cline { 2 - 4 } Age (years) & $19.6 \pm 2.6$ & $20.8 \pm 2.8$ & $21.1 \pm 0.6$ \\
Body height $(\mathrm{cm})$ & $179.2 \pm 8.1$ & $176.4 \pm 5.2$ & $181.5 \pm 8.7$ \\
Body mass $(\mathrm{kg})$ & $82.7 \pm 19.4$ & $80.1 \pm 13.9$ & $79.1 \pm 11.2$ \\
BMI & $25.6 \pm 4.0$ & $25.1 \pm 2.5$ & $24.0 \pm 1.8$ \\
$\begin{array}{l}\text { Training experi- } \\
\text { ence (years) }\end{array}$ & $9.6 \pm 2.1$ & $7.9 \pm 1.0$ & - \\
\hline
\end{tabular}

Thigh muscle strength was measured under isokinetic conditions using "Easy-Tech" dynamometer in concentric-concentric mode according to standard protocol, the subject in sitting position. Prior to every test the machine was calibrated, ROM was set at $90^{\circ}$, and a warm-up, consisting of bicycle run and stretching of quadriceps and hamstring muscles, applied. A more specific warmup consisted of $3-4$ repetitions at the testing speed (60 $\mathrm{deg} / \mathrm{s}$ ) for both quadriceps (knee extensor) and hamstring (knee flexor) muscles in order to prepare the 
subject for regular testing. After 2 min the subjects performed 4 repetitions of maximal voluntary contractions of thigh muscles. The same person conducted all measurements and the same protocol was used for both legs $[8,10]$.

Relative peak values of thigh muscle torques were recorded: right and left knee extensors (KE-R and KE-L, respectively), and right and left knee flexors (KF-R and KF-L, respectively). Functional asymmetry was defined as absolute lateral difference (disregarding the sign) expressed as percentage of the muscle torque of dominant side. The flexor-to-extensor ratios were computed and expressed in percentages. The data were subjected to one-way ANOVA with post-hoc Newmann-Keuls's test, the level of $\mathrm{p} \leq 0.05$ being considered significant.

\section{Results}

The results of muscle torque measurements for knee flexors and extensors are presented in Table 2, the ratios of flexor-to-extensor torques in Table 3 and absolute percent asymmetry indices in Table 4. Judoists and wrestlers were evidently superior to the untrained individuals wit respect to peak muscle torques. No significant differences were found between wrestlers and judoists in individual muscle groups but wrestlers had significantly $(\mathrm{p}<0.05)$ higher torques of all muscle groups combined than the judoists. The values recorded in untrained subjects were lower than those in athletes but only few differences were significant (cf. Table 2).

Table 2. Mean values $( \pm \mathrm{SD})$ of relative peak muscle torques of the knee joint extensors

\begin{tabular}{lccc}
\hline & Judoists $(\mathrm{n}=10)$ & Wrestlers $*(\mathrm{n}=10)$ & Untrained $(\mathrm{n}=10)$ \\
\hline KE-R & $3.28 \pm 0.49(2.6-4.0)$ & $3.47 \pm 0.51(2.7-3.8)$ & $2.87 \pm 0.44^{\mathrm{w}}(2.1-3.6)$ \\
KE -L & $3.12 \pm 0.50(2.0-3.8)$ & $3.60 \pm 0.64(2.7-4.6)$ & $2.77 \pm 0.34^{\mathrm{jw}}(2.3-3.3)$ \\
KF-R & $1.57 \pm 0.40(1.0-2.3)$ & $1.36 \pm 0.20(1.1-1.7)$ & $1.20 \pm 0.22^{\mathrm{j}}(0.9-1.5)$ \\
KF-L & $1.41 \pm 0.25(1.2-2.0)$ & $1.42 \pm 0.38(1.0-2.1)$ & $1.14 \pm 0.27(0.7-1.6)$ \\
\hline
\end{tabular}

Legend: KE - Knee extensors; KF - Knee flexors; R - Right; L - Left; Significantly ( $<<0.05)$ different from wrestlers $\left({ }^{\mathrm{w}}\right)$ or judoists $\left({ }^{\mathrm{j}}\right)$; * Significantly $(\mathrm{p}<0.05)$ higher than in judoists for both ratios combined

Table 3. Mean values ( \pm SD) of flexor-to-extensor ratios (\%) for right and left legs

\begin{tabular}{llll}
\hline & Judoists & Wrestlers * & Untrained \\
\hline $\mathrm{R}$ & $47.8 \pm 10.8$ & $39.5 \pm 4.9$ & $41.8 \pm 5.7$ \\
$\mathrm{~L}$ & $45.9 \pm 9.1$ & $39.3 \pm 6.0$ & $41.0 \pm 8.5$ \\
\hline
\end{tabular}

* Significantly $(\mathrm{p}<0.05)$ lower than in judoists for both ratios combined

Table 4. Mean percent values $( \pm S D)$ of absolute rightleft asymmetry of relative peak muscle torques and of flexor-to-extensor ratios

\begin{tabular}{cccc}
\hline & Judoists & Wrestlers & Untrained \\
\hline $\mathrm{KE}$ & $8.6 \pm 7.7$ & $8.4 \pm 4.9$ & $7.2 \pm 6.8$ \\
$\mathrm{KF}$ & $14.6 \pm 10.4$ & $17.4 \pm 11.8$ & $14.6 \pm 11.7$ \\
$\mathrm{KF} / \mathrm{KE}$ & $4.06 \pm 3.19$ & $6.71 \pm 3.84$ & $5.63 \pm 4.57$ \\
\hline
\end{tabular}

All individual asymmetry indices are significant $(\mathrm{p}<0.01)$

The flexor-to extensor ratios for the right and left legs combined were in wrestlers significantly lower than in judoists (Table 3). When absolute right/left differences (i.e. greater value - smaller value) between muscle torques of knee flexors or extensors were computed and expressed in percentages of greater (right or left) value, the resulting lateral asymmetry indices were significantly $(\mathrm{p}<0.01)$ higher for flexors than for extensors, no significant between-group differences being detected; this was also true for the asymmetry in flexor-to-extensor ratios (Table 4).

\section{Discussion}

The lateral asymmetry in peak muscle torques may be obscured by individual dominance of the right or left leg. For that reason, mean values presented for the right and left legs may not reflect the sport-specific features. Therefore, asymmetry indices were computed; these reflected absolute right/left differences, i.e. higher of the two values had been attributed to dominance of given leg. That asymmetry, amounting to about 8 and $15 \%$ for extensors and flexors, respectively, was in all groups alike. This suggests that neither wrestling nor judo induced a more pronounced asymmetry in thigh muscle strength than that typical of untrained subjects. Thus, specific judo throwing techniques (Uchi-mata, Haraigoshi, Osoto-gari and Ouchi-gari) [2,3,6,11] and sportrelated development of movement patterns proved safe regarding the risk of marked functional asymmetry. The 
main difference between judo and wrestling is in the throwing technique; in wrestling, static contractions are more frequent and high absolute strength is essential in athletic performance [5]. This was reflected by significantly stronger thigh muscles (all studied muscle torques combined) in wrestlers than in judoists.

Flexor-to-extensor ratios in untrained subjects were similar to those reported by Borges [1]. Interestingly, the combined (right and left) ratios were in wrestlers significantly lower than in judoists which is suggestive of a functional dominance of flexors in judoists and of extensors in wrestlers, although no significant differences were found for muscle torques. That imbalance may be due to differences in movement patterns and types of exertions specific for both sports.

In conclusion, movement patterns in judo and wrestling are extremely demanding for thigh muscles. Thus, the training means and methods for improving strength and endurance ought to be carefully selected and adjusted. Implementing new training elements and modalities may improve the performance and prevent lateral asymmetry thus decreasing the risk of injuries.

\section{References}

1. Borges O. (1989) Isometric and isokinetic knee extension and flexion torque in men and women aged 20 - 70. Scand.J.Rehabil.Med. 21:45-53.

2. Branco J.C. (1979) A observaçao no judo - recolha efectuada nos campeonatos nacionais de 1979 (por categoria de peso). Ludens 3(4):30-52.

3. Brown C., G.McMurray (1996) Olympic judo statistics - technique utilization and effectiveness. www.engr.orst.edu/ odoms/statistics.htm Judo page www.engr.orst.edu/ odoms/judo.htm 4/3/97.

4. Drid P., M.Dokmanac (2007) Utjecaj bazičnog trenažnog programa na snagu hrvača juniorskog i seniorskog uzrasta. [Effects of basic training program of junior and senior wrestlers on strength]. In: I. Jukić, D.Milanović, S.Šimek (eds.) 5. godišnja međunarodna konferencija: Kondicijska priprema sportaša pp. 331-335. Kineziološki fakultet Sveučilišta u Zagrebu i Udruga kondicijskih trenera Hrvatske.

5. Drid P., M.Dokmanac, S.Obadov, S.Vujkov (2007) Trening u funkciji razvoja maksimalne snage vrhunskih rvača. [Training in function of developing maximal strength in elite wrestlers]. In: G.Bala (ed.) Antropološki status i fizička aktivnost dece, omladine $i$ odraslih, 371377. Novi Sad: Fakultet sporta i fizičkog vaspitanja.

6. Drid P., M.Drapšin, S.Obadov (2007) Odnos mišićne snage agonista i antagonista natkolenice kod vrhunskih džudistkinja. [Relevance of muscle strength of hamstring agonists and antagonists in elite female judoists]. In: N.Smajlović (ed.) II međunarodni simpozijum nove tehnologije u sportu, 208 - 210. Sarajevo: Fakultet sporta i tjelesnog odgoja.

7. Franchini E., M.Y.Takito, M.A.Kiss, S.Sterkowicz (2005) Physical fitness and anthropometric differences between elite and nonelite judo players. Biol.Sport 22: 315-328.

8. Gleeson N.P., T.H.Mercer (1996) The utility of isokinetic dynamometry in the assessment of human muscle function. Sports Med. 21(1):18-34.

9. Kraemer W.J. (2002) Periodized training programmes for athletes. In: W.H.Kraemer, K.Hakkinen (eds.) Strength Training for Sport. Blackwell Science, Oxford, pp. $101-108$.

10. Madsen O.R. (1996) Torque, total work, power, torque acceleration energy and acceleration time assessed on a dynamometer: reliability of knee and elbow extensor and flexor strength measurements. Eur.J.Appl. Physiol. 74:206-210.

11. Sterkowicz S., P.Maslej (1998) An evaluation of the technical and tactical aspect of judo matches at the senior level. International Judo Coaches Alliance Site: www.judoamerica.com/ijca/sterkowicz/index.html.

12. Thomas S.G., M.H.Cox, Y.M.Legal, T.J.Verde, H.K.Smith (1989) Physiological profiles of the Canadian National Judo Team. Can.J.Sport Sci. 14:142-147.

Received 23.10.2008

Accepted 21.02.2009

(C) University of Physical Education, Warsaw, Poland 